\title{
The deprivation of certitude, legitimacy and hope: For eign national prisoners and the pains of imprisonment
}

Criminology \& Criminal Justice

(C) The Author(s) 2015

Reprints and permissions: sagepub.co.uk/journalsPermissions.nav DOI: $10.1177 / 1748895815603775$ crj.sagepub.com @SAGE

\author{
Jason $\mathrm{W}$ arr \\ University of Lincoln, UK
}

\begin{abstract}
At the end of March 2015 there were 10,481 foreign nationals (defined as non-UK passport holders) held in prisons in England and Wales, representing 12 per cent of the overall prison population. The latest published figures from December 2014 also indicated that there were a further 394 immigration detainees also being held in various prisons, rather than Immigration Removal Centres, across England and Wales. Although Sykes's deprivation model with its associated 'pains of imprisonment' has been exhaustively explored by penologists, this article argues that there are a new range of 'pains' uniquely faced by foreign national prisoners in England and Wales who come under the scrutiny of the Home Office's Immigration Service. Drawing on quasi-ethnographic fieldwork in a Specialist Foreign National Prison, this article discusses the new pains relating to a lack of certitude, legitimacy and hope with regard to both their carceral and post-carceral lives.
\end{abstract}

\section{Keywords}

Deprivations, foreign national, imprisonment, pains, prisoners

In an article entitled 'Refugees in a carceral age: The rebirth of immigration prisons in the United States', Jonathan Simon (1998) forewarned of a political shift towards the imprisoning of refugees. He argued that public and political attitudes changed in the wake of the Mariel Boatlift incident, which saw an estimated 100,000 Cubans enter the Florida coastline between April and October 1980 (Engstrom, 1997), into a more ideologically punitive reflexion upon issues of immigration. Simon contended that this attitudinal shift created a political impetus that carried through the 1980s into the 1990s, resulting in immigration policy that utilized imprisonment as a mutated 'technology of power' which he speculated would shape the carceral landscape in the United States far into the future. Mary Bosworth (2014), and previously with Emma

\section{Corresponding author:}

Jason Warr, School of Social \& Political Sciences, University of Lincoln, Brayford Pool, Lincoln, LN6 7TS, UK.

Email: jwarr@lincoln.ac.uk 
Kaufman (Bosworth and Kaufman, 2011), noted that though Simon's argument was 'prescient' in many ways, it is not the refugee who has become the focus of this politico-carceral shift but instead those persons whom governments - in the USA and elsewhere - label as 'alien others'. For Bosworth (2014) and Bosworth and Kaufman (2011) (see also Hernandez, 2013; Schuck, 2013), these alien others are not just refugees but can also include undocumented workers, trafficked persons, resident but alien 'enemies' and other designated 'non-citizens'. They argue that these specialized populations are subject to new matrices of political, carceral, ethical and practical discourses that render them hidden from much contemporary criminological inquiry.

As Bosworth (2011) highlights, though the immigration/imprisonment nexus had gained ground throughout the 1990s and early 2000s in England and Wales, it was the advent of the 2007 UK Borders Act, and the subsequent Borders, Citizenship and Immigration Act 2009 (which further eroded the legal status of immigrants), that consolidated and entrenched this practice. The former Act declared that every nonEuropean Economic Area (EEA) prisoner with a sentence of more than 12 months and every EEA prisoner with a sentence of over 24 months would henceforth be designated as a 'foreign criminal' and would, as a matter of Home Office priority, be earmarked for mandatory deportation and expulsion from the country. Indeed, since 2010, 23,000 foreign national offenders have been removed or deported from the country (PRT, 2015). The legal status and situation of foreign national prisoners has been further compounded by the Immigration Act 2014 which has placed limits and restrictions on the right of appeal against immigration decisions, and awarding the Home Secretary extra powers with regard to the removal of citizenship (Home Office, 2014). These policy machinations, as will be further explored below, have resulted in a consistent and steady growth in the number of foreign national prisoners being held in the prisons of England and Wales. At the end of March 2015, there were 10,481 foreign nationals (defined as non-UK passport holders) held in prisons in England and Wales, representing 12 per cent of the overall prison population. However, as of 15 December 2014, there were also 394 immigration detainees also held in various prison establishments rather than Immigration Removal Centres (IRCs) (PRT, 2015). ${ }^{1}$ As the administrative systems improve and increased funding for the management of foreign national offenders (FNOs) come into effect it is expected that these numbers will increase (NAO, 2014).

Taking Sykes's (1958) deprivation model as a starting point and extending Bosworth's (2011, 2014) analyses on the experiences of foreign national prisoners and detainees, this article argues that the designated foreign national population within the prison estate of England and Wales represents a distinct population which faces a new range of 'pains' that both consolidate and exacerbate those experienced by British prisoners (see Bhui, 2004, 2007). These new pains relate to a lack of certitude, legitimacy and hope with regard to both their carceral and post-carceral lives.

\section{Methodology}

This article is based on my experience of working on behalf of a third sector organization in a mid-sized $(600+)$, medium secure prison ${ }^{2}$ with a significant, quickly turning-over foreign national prisoner population. Over the 30 month period of 
working in this particular establishment, and as a direct consequence of the hubs and spokes agreement between the National Offender Management Service (NOMS) and the UK Border Agency (UKBA) (Kaufman, 2013; MoJ and UKBA, 2009), the population changed from a mix of sex offenders (60 per cent) and foreign nationals (40 per cent) to a fully foreign national special function prison.

My role was to act as an independent and objective Prison Council facilitator, commissioned and contracted by the prison, which involved engaging both formally and informally with prisoners and staff and to then assist prisoners, and interested staff, to collate their collective experiences of the prison and report them to the prison's Senior Management Team in a coherent, structured and solution-focused manner. A further role was both to observe and report on the prison, via the management structure of the charity and in written monthly and annual reports, directly to the governing Governor with regard to issues and problems that were noted within the prison. These reports were based upon the experiences of myself and a colleague who worked with me in the prison, the formal data that we collected on issues raised/actioned through the prison council and experiences and quotes of prisoners and staff garnered during our interactions. Informed consent was sought for any and all quotes, case studies or instances reported. If consent was not given or if language barriers raised questions over the veracity of informed consent then quotes were not recorded in the field notes and case studies omitted from reports. During this period I was commissioned to write a chapter for the revised second edition of the Handbook on Prisons (Warr, forthcoming) and permission was sought and given from this prison and a Young Offender Institute, where I performed the same role, to inform that and other academic publications with my experiences of working in those establishments and material detailed in field notes. I was not there primarily to conduct academic research; however, my role was to explore and relay the experiences of those I worked with and this process was informed by my academic experience, the protocols of the charity by whom I was employed, the needs of the prison and my experiences as a multi-ethnic former prisoner.

As the variegated roles described here suggest the role I performed within this prison and the identity I had within went beyond that of the normal researcher. However, in terms of methodology this article is akin to the tradition of other 'insider research' (Hodkinson, 2005) whereby there is, at the outset at least, a degree of contiguity and commonality between the observed community and the commentator. This 'insider' positionality both presents benefits as well as risks and some of this complexity will be discussed below. What is important to note though is that this article, following this and other (quasi-)ethnographic traditions, seeks to communicate the complexities of the lived experience in this prison without relying on the abstracted neutralizations often found in criminological literature (Jewkes, 2011).

As Hopkins (2007) notes it is important to acknowledge and consider the relationship between researcher and researched and the manner in which relational matrices (similarities, differences, commonalities, intentions and, of course, power) and the subjective positionality of the researcher impact on research practice and results. In this instance it is evident that I was performing multiple 'roles' and occupying multiple 'positions', the combination of which raises ethical implications for the data utilized and the argument outlined in this article (Soni-Sinha, 2008). This tripartite positionality, facilitator/former prisoner/researcher, coupled with my mixed ethnicity, gender and social class (what Earle (2013: 18) has referred to as the 'persistent trialities 
of social science'), afforded me a great deal of personal access and enabled prisoners to 'open up' about their issues and experiences in ways they may not have if my 'cultural competence' (Hodkinson, 2005: 138) was not recognized, if there were not some shared experiences and the acknowledgement that our role there was to help improve the lives of those who inhabited the prison. This is of course a double edged sword as this relationship could impose a reflexive bias in that our aims of improvement, as opposed to discovery/explanation, may have encouraged respondents to shape their responses to this end (Thapar-Bjokert and Henry, 2004). A further problem of positionality relates to that of shared experiences and how this shaped the relationship between the foreign national prisoners and myself and the manner in which I interpret the information/narratives they proffered. Jewkes (2014) argues that research is an emotional endeavour and that our own experiences can shape how we collect, respond and report that which we research. Obviously in this regard my own history, and its emotional impact, could greatly impact on the content of this article. In order to address these concerns I have very carefully only used material where explicit permission was given, where that permission was assuredly informed and which supported positions and experiences widely or pervasively held.

While in the prison, I had a significant degree of contact with the majority of staff, consistent and weekly contact with an evolving but core group of 100 prisoners and sporadic contact with a further 100 or so prisoners. I had the space and freedom to interact and talk to those living within the prison in their own spaces (wings, cells, association areas, etc.) as well as in more formal settings. This enabled a much more thorough immersion in the informal life of the prisoners and a greater examination of the issues they raised since matters could be revisited on numerous occasions and in different settings in order to establish their specificity and prevalence. In this regard, the approach presented in this article can be thought of as quasi-ethnographic and, as mentioned above, similar in nature to the 'insider research' conducted by researchers in differing contexts such as Hodkinson (2005) and Teusner (2015) and resembled the method utilized by Cohen and Taylor (1972) in their work on long term imprisonment. In the course of the 30 months spent engaging with the population, it became apparent that there were novel and population specific issues being raised. These are reflected upon in light of the relevant penological and foreign national prisoner literature and other novel discoveries on the 'pains' of imprisonment.

The establishment had experienced a number of problems in the period under discussion. As with other public sector establishments, the prison had been subject to a benchmarking exercise (NOMS, 2013) that many staff felt had resulted in a degree of asset stripping from the prison, which had led to both a reduction in staffing levels and problematic staff sickness levels. There had been three changes in governing Governor and fundamental alterations to the Senior Management Team in terms of both personnel and management functions. There had also been three core regime changes leading to a great deal of uncertainty about the regime being delivered within the prison. There were also wider, organizational and ideological changes brought about by the then Justice Secretary Chris Grayling's moulding of a more austere and punitive prison policy. Coupled to these issues there was the change in function and duties that had arisen due to the hubs and spokes policy and its attendant, and problematic, fusing of carceral priorities (Kaufman, 2013). Under these conditions, the prison suffered: 
there was an increase in general disorder and the level of interpersonal violence; there were a number of deaths in custody in a short period; and, eventually, an incidence of mass disorder on one particular wing. This backdrop both contributed to the subsequent new pains to be discussed below or had, in the case of the incidence of disorder, arisen because of these new pains.

\section{Literature Review}

In The Society of Captives, Sykes (1958) argued that imprisonment is characterized by a set of distinct, yet co-morbid and mutually reinforcing, deprivations that engender what are referred to as the 'pains of imprisonment'. He identified five core deprivations: liberty; security; autonomy; goods and services; and heterosexual/social relationships. Complementing this argument, and in many ways explicating the mechanics of the depriving circumstance, Goffman (1961) added that a core function of any carceral institution is the decortication, or stripping, of an individual's pre-carceral identity, achieved via a process of 'mortification', in order to impose a more desirable 'inmate' identity. These pains/mortifications not only mark the carceral experience but have a major psychological impact on prisoners and can determine their survival within the prison (Crewe, 2009, 2011; Toch, 1992) and beyond (Maruna, 2001). The deprivation and mortification model has influenced penological thought since the 1960s and has led to the identification of a number of further 'pains' experienced by specific and/or special populations.

For instance, Carlen (1983), Rowe (2012) and Walker and Worrall (2006) argue that women, who are largely imprisoned in environments designed for men, constitute a special carceral population who suffer a multitude of pains and mortifications that go beyond those experienced by men. These gender-specific pains can include issues such as the deprivation of gender identity (being assigned gender typifications or expected to conform to gendered stereotypes), deprivation of self-determination (offending behaviour being pathologized in ways that men's is not), deprivation of femininities (being sentenced and treated as if they were male offenders), familial role (both imposed patriarchal ideation and/or the erosion of their role as a primary care giver) and deprivation of 'bodily or emotional privacy' (the various types of violational acts to which women prisoners are subject (Carlen, 2013).

Likewise, Cesaroni and Peterson-Badali (2010), Fagan and Kupchik (2011), Reich (2010) and Van Der Laan and Eichelsheim (2013) have argued that juvenile and young offender prisoners can also be considered special populations as they suffer pains in ways not experienced by adult populations. These pains include deprivations such as safety, whereby the young are more vulnerable to various forms of predation; and of trauma recognition, where they are seen as dangerous offenders which can blind authorities to the fact that they may also be the victims of violence and abuse. Related to this latter factor can be a deprivation of well-being as they receive no aid in coming to terms with their own traumas and thus psychological, emotional and health needs may go unmet. Young prisoners may also suffer the deprivation of pro-social maturation whereby they are forced to mature in toxic environments with negative rolemodels and constrained social relationships.

Crewe (2009, 2011), Jewkes (2005) and Mason (1990) similarly highlight the special nature of those serving life and indeterminate sentences who can suffer long term exposure to the Sykesian pains, in addition to being confronted by a specific range 
of pains that relate to their sentence type. Some of these deprivations can relate to the decortication of a natural (or non-offence related and risk laden) identity and the subsequent ontological insecurity that can derive from that loss. A further issue is the manner in which Lifers are transformative risk subjects (Hannah-Moffat, 2005) where many of their needs are interpreted as risks that need managing. Crewe (2009) notes this positioning makes it difficult for Lifers to address those needs without potentially raising their risk profiles which imposes negative consequences for sentence progression. However, there were also identified issues around the deprivation of certainty (navigability) and, particularly with regard to those convicted under the common law principle of joint enterprise, a deprivation of legitimacy (Crewe et al., 2014). These last two deprivations are particularly important for this article and as such shall be explored in more depth.

While other authors (e.g. Jewkes, 2005; McDermott and King, 1988; Rotman, 1990) highlight the level of uncertainty faced by life and indeterminately sentenced prisoners in terms of securing progression and release, this notion of uncertainty as a specific pain was explicated by Crewe (2011). He argued that for the 13,000 prisoners serving the various indeterminate sentences in England and Wales at the time, a number of factors define the deprivation of certainty. These include: a distinct potential (and unknowable) degree of separation between the end of tariff and release; the complexity of sentence structure; the attendant bureaucracy and administration meant that a 'routemap' was impossible to discern; that a 'fog of uncertainty' with regard to the fundamental aspects of the sentence (e.g. sentence length, risk calculation and reduction, placement and transfer) was inherent to the sentence type; and that goalposts could be shifted and aims made unattainable at the whim of the various penal authorities to whom they were subject. Together, these factors resulted in a situation whereby indeterminate prisoners felt unable to navigate their sentences effectively and thus could not determine an ontologically secure future, resulting in a distinct and significant pain.

With regard to the deprivation of legitimacy, Crewe et al. (2014) found that these problems of navigability were compounded for those where the principle of joint enterprise had been utilized to secure their conviction. ${ }^{3}$ The use of this common law doctrine is controversial and has created a new body of Lifers. It is beyond the scope of this article to explore these issues. However, Crewe et al. (2014) explain that this body of Lifers do not perceive their sentence, and thus their incarceration, as legitimate as they did not perceive themselves as principally guilty of the offences for which they were serving life sentences, often with very long tariffs. This ontological position was both an exacerbating factor in terms of their other (more traditional) pains and as a distinct pain in and of itself. Indeed, the deprivation of legitimacy meant they could not accept the other pains of their imprisonment as a necessary aspect of their punishment because the punishment itself was perceived as unjust. Additionally, the very grounds upon which they were able to measure their treatment as prisoners was deprived to them since that position was predicated upon it being a just position.

Notwithstanding all of the above accounts, little penological attention has been given to the specific deprivations faced by foreign national offenders. ${ }^{4}$ It is to this population that I now turn. Bhui $(2004,2007)$ highlights the specialized nature and needs of the foreign national prisoner population in England and Wales. He identifies 
the complexity of their carceral experiences and resettlement needs and argues that these are poorly met by the NOMS structure and the risk models employed therein. However, he also identifies (see also Bosworth, 2011; Kaufman, 2013) the turning point in the treatment, and subsequent experience, of foreign national prisoners as being the scandal that arose in 2006, after it was revealed by a National Audit Office (NAO, 2005) report that in the previous seven years 1000 foreign national prisoners had been released and not deported. This 'crisis' and subsequent scandal led to the resignation of the then Home Secretary Charles Clarke, an intensification in the antiimmigration rhetoric in both the national media and parliament and, as noted by Kaufman (2013), eventually the hubs and spokes agreement between the Ministry of Justice and UK Border Agency. This agreement (MoJ and UKBA, 2009) established a 'panoptic' model for the management and administration of 'incarcerated foreigners' whereby they would be concentrated in hub or spoke prisons under the direct purview of Immigration personnel (Kaufman, 2013). This fusing of government agencies, with competing priorities and codes of practice, has fundamentally changed the carceral experiences of foreign national prisoners as well as the working practices of prison staff who work with them (for further discussion of these issues see Kaufman, 2015). It is these changed experiences and working practices that generate the new deprivations of certitude, legitimacy and hope experienced by this population.

\section{Deprivation of Certitude}

Foreign national prisoners in this establishment were, as with others in differing immigration settings (Bosworth, 2013), often unsure when their carceral period would end. Such uncertainty was experienced by all those whose sentences had yet to finish but had been moved to the prison as their immigration status was in question, those who had been notified of the intent to remove them and those who were being held beyond the end of their sentences in prison - either because they were still fighting their deportation and trying to resolve the issue of the immigration status or because the details of their removal had yet to be resolved. This latter group included some who had signed up to the voluntary early return schemes as evidenced by one individual from South America who had signed to return nine months before the end of his sentence but was still in the prison 12 months after the end of his sentence as the travel documentation had not been issued by the authorities of his home country.

Foreign national prisoners have to contend not only with the opaque bureaucracy of the criminal judicial system and the institutions in which they are housed in but also with the increasingly labyrinthine Immigration apparatus and policies of the Home Office. Navigating these bureaucratic sink-holes when English was not a first language posed additional challenges. It was not uncommon to be given paperwork involving complex immigration policy and law, in English, to complete and return within a week. Access to formal translation and translators was limited, leaving many dependent on informal peer translators who did not necessarily have any more knowledge of the systems in place than those they were trying to aid:

The guvs here don't know nothing fam. You ask, they shrug. Them tell you to speak to Immigration but all them interested in is deporting ... Them do it on purpose you know fam? Them don't want you knowing this shit, the law, the process, how to fight and to appeal. Them want you gone fam ... and them keep you fucking ignorant to make sure you gone. 
As this quote, from a Ghanaian born individual who had lived in London for most of his young life, indicates there was a level of epistemic ignorance within the prison, at all levels, with regard to Immigration policy that would contribute to this deprivation of navigability. Also, as staff numbers were reduced in the prison there was a corresponding loss of expertise among the remaining staff. As such the only recourse staff had in order to try and answer prisoner queries was to refer them to the Immigration officers who operated in the prison. As Kaufman (2013) has argued the hubs and spokes agreement had formalized this arrangement and had turned prison officers into Immigration/UKBA 'postmen' whose role it was to facilitate their processes. However, the front line uniformed staff here had been a largely engaged staffing population when dealing with the previously mixed population and were used to answering queries and aiding prisoners with their cases. Now they had little information or expertise to utilize and many found this a source of frustration as one staff member noted 'We can't help these lads now, what do we know about immigration appeals? All we can do is pass them on to them [Immigration] and that's ... that's frustrating for everyone.'

Prisoners tended to be sceptical of Immigration officers. Many felt that they were not there to help, that they had an overt agenda of misinformation and that they were not always open and honest in their dealings with either the prison management or the prisoners. Matters were made worse when a lead team member stated explicitly in a prison council meeting with prisoner representatives and the Senior Management Team that her job was not to help the prisoners resolve their cases but to remove them from the country. It was not her job to care about a prisoner's family, she later stated, but to return him to the country in which he had been born. ${ }^{6}$

Like Lifers foreign national prisoners did not know how long the gap between the end of the sentence and their release would be. Compounding matters, they did also not know where that release would be to. One man had made plans to return to his partner's home in London where he had previously resided. The day before release he was issued with a notification (IS91) from Immigration that they intended to deport him. This had prevented his release and he stated that he no longer knew where he stood or where his family stood in terms of his release. He had been denied bail and was struggling to explain to his partner and their children why he had not come home and why he may never come home. Under these circumstances, he could not plan for the future as he could not possibly know what that future would look like. Another prisoner, a Kurdish man, stated that:

22 years I been in this country. 22 years. I told you, I work, I own house, I have family ... I come to prison they give me IS91 and move me here. Now they want to send me back to [omitted]. I have not been there since family left when I child. I fight! But no help here to fight. They tell me 'our job is to get you out of country' ... Now I do not know what to do or where I am go.

This inability to envisage a future caused significant distress among the prisoners as their perception, and ability to perceive, their 'outside' lives were inherently insecure (see also Bosworth, 2014). They feared also it would be held against them when they went before the courts as it was perceived as a lack of ties to family and community 
thus undermining their applications. In this sense, many observed, they were doubly punished (Kruttschnitt et al., 2013).

In these regards the deprivations experienced by foreign national prisoners resemble those of Lifers. However, the degree of deprived certainty went beyond that described here to include factors which impacted on the very confidence that they could have regarding the system to which they were subject. Though the situation of Lifers is often opaque and navigability is compromised there are still distinct 'protocols' by which they and their life course is governed within the penal institution - though they may suffer under this system they can believe that there are rules and these must be adhered to. In this particular prison, and for the foreign nationals held there, no such confidence existed, in either the prison or in immigration as this account from a white southern African prisoner reveals:

It's like that Little Britain sketch 'Computer says no' except here it’s 'Immigration says no'. Don't matter what you ask for it just comes back 'Immigration says no'. ROTL [release on temporary licence]? 'Immigration says no'. Offending Behaviour course? 'Immigration says no'. OU [Open University]? 'Immigration says no'. It’s a fucking joke. Even applications about things enshrined in PSOs and PSIs get run past Immigration and if it don't fit their agenda then ... 'Immigration says no'. We get nothing now. As [omitted] said, this aint a prison anymore as the prison rules don't apply... it's an internment camp.

In the period immediately after the transition to a special foreign national prison it became evident that many of the regulations that prisoners were used to relying upon in their day to day interactions with the institution had been subsumed under the interests of Immigration. Prior to this point prisoners knew that if they quoted a Prison Service Order then there was a chance that their complaint/application would gain some ground. However, as the hubs and spokes policy began really to determine practice within the prison matters changed dramatically (MoJ and UKBA, 2009). Bhui (2004) noted that the reality of a deportation order, or even immigration/UKBA interest, can negatively impact on the risk assessment process and thus hamper foreign national prisoners from accessing such schemes as release on temporary licence (ROTL). The subsequent hubs and spokes policy further compounded this as it prioritized the prison's role in the government's 'wider deportation [and immigration] strategy' (Kaufman, 2013: 170) and as such ideations of rehabilitation and resettlement were largely forsaken in the interests of detention and deportation. Therefore, in comparison to the situation before the transition, foreign national prisoners found it immensely difficult to access a range of prison programmes/initiatives, from ROTL, offending behaviour courses and even to study with the Open University.

This loss of surety in the prison rules resulted in foreign nationals feeling adrift in terms of their prisoner footing and any confidence they had once had in the governance of their treatment. What compounded this issue was that the prisoner body was aware of their own gaping lacunae of knowledge with regard to immigration policy/law and were acutely aware, as the quotes here indicate, that little succour was to be gained from either prison or immigration staff. Many of the prisoners understood this situation and did not place any blame on the uniformed body but nevertheless it added to their sense of being adrift - as their first point of contact for information and aid was largely unable to offer any information or aid. 


\section{Deprivation of Legitimacy}

After the Woolf (Home Office 1991) inquiry into the prison disturbances of Strangeways, Pucklehurst and others in the latter years of the 1980s, the notion of justice, and subsequently legitimacy (Sparks et al., 1996), became a prevailing sentiment in penal discourse (Carrabine, 2005). In the intervening period the notion of legitimacy has become something of a temperature gauge for measuring the distance between the actions of prison authorities and the willingness of prisoner populations to accept the terms of their incarceration (for a fuller discussion see Liebling and Arnold 2004; Loader and Sparks, 2013). However, as was noted above, the manner in which legitimacy is conferred, and the process of legitimation, can sometimes be contingent on the manner in which specific populations perceive not only their treatment but also their situation.

Often perceived as procedural justice (Bottoms and Tankebe, 2012) within this particular discourse the fact is that the notion of legitimacy is far more complex, involving a more subtle set of interactions. It is clear that how prisoners perceive the issue of legitimacy often goes beyond procedural considerations to their perception of the justification of their position - which more closely resembles the description of legitimation given by Wrong (1995) which indicates that the power/authority of the principal (power holder) is legitimated when, and only when, the subaltern (power recipient) accepts and shares the values which underpin the power being wielded. It is in this sense that many of those sentenced under the principle of joint enterprise mentioned above judge their incarceration. They do not accept the type of conviction they have received and thus cannot perceive the justification of the punishment/sentence imposed as being legitimate. In effect the very means by which they could legitimate their experience of incarceration is eroded and deprived.

A similar perception was evident among the foreign national prisoners. Although they may have accepted their initial imprisonment for their wrongdoing (their criminality) as this elderly West Indian prisoner noted '[w] was hard, you know? But you get your head down, you get on with it because ... you know? You've done something bad, it's okay, you take it', the potential ongoing incarceration, which is not dependent on any criminality or necessarily notions of dangerousness or risk, coupled with the deprivation of certitude discussed above, resulted in a situation whereby the means by which they were able to judge their placement as prisoners was compromised. As this middle aged Polish man noted:

I am no longer prisoner. I do crime, I do time. Still I am in prison. Why is this? You tell me why this is? You think it is right that I am in prison when my sentence finish? You know what prison does to you? Why must I suffer here? This fucking government. I tell you. They want us to suffer because we not born here, they like fucking Hitler Nazis.

Second, as many of the normal prison rules and regulations were subsumed under the immigration agenda many foreign national prisoners felt that their special status meant that they were being treated differently from the wider prisoner population; as one prisoner, supported by others, asked a member of the SMT 'is this still a prison, because we are no longer treated like prisoners?' This positionality and differentiated treatment meant that any shared value base that existed with regard to the justification 
of their incarceration was eroded and, in many regards, resulted in a withdrawal from the legitimation process - leading to a consequential legitimation crisis (Habermas, 1975) - and the instance of mass disorder noted above.

However, there were other factors that impacted on these issues that further undermined the legitimation process. Bosworth (2013) argues that in an age of global mobility the complexity of interaction between detainee, the removal centre, the sovereign state and diverse external states challenges common penological notions of legitimacy in carceral settings. She argues that the power of the state is both more diffused and potent in IRCs and that this experiential reality impacts on how we can interpret the matrices of penal power to which immigrants are subject and thus how we understand the notion of carceral legitimacy. The intrusion of external principles into the power dynamics, bureaucratic processes and quotidian life within IRCs highlights the need to look beyond the 'internal life' of the institution and how this relates to the justifications of its being in order to examine questions of legitimacy. Thus for foreign national prisoners we cannot simply locate legitimacy in their experience of conditions but must look beyond this to those external elements that impact on how they perceive their incarceration and its justification.

All prisoners are subject to political whim and the vagaries of political rhetoric. As Tonry (2004) notes the politics around punishment, especially the 'tough on crime' rhetoric that has haunted British politics since the early 1990s, can have both formal and (insidiously) informal consequences on punitive attitudes and practices. Wood and King (2014) argue that a very similar process is occurring with regard to immigration issues and the British press whereby, on a nearly daily basis, the negative, moral panic inducing, rhetoric that exists around immigrants and foreign national prisoners especially since the rise and influence of the UK Independence Party (UKIP) on the political landscape - has a distinct power both to 'reflect and shape' public attitudes. The prisoners being held in this establishment were acutely aware of this negative reporting and located both the justification of their imprisonment and the cause of their perceived ill-treatment in this political motivation. For example one prisoner, an Iranian man whose family had been granted asylum decades previously, had claimed that the situation of foreign national prisoners had deteriorated in the prison since the high profile case of Abu Qutada: ' ... now? We don't deserve this!? Just because May had problems with Qutada we all got to suffer? It's not right.' While another spoke of the way in which general political feeling shaped the responses of staff: 'You hear them talk about immigrant in bad way, like Daily Mail, like UKIP, this why we treat like this, they don't like us, they don't want us here.' It was felt by many of the prisoners that the staff were unwilling to help them, to allow Immigration to run roughshod over them and to compound their positionality because of these political sentiments. The veracity of this perspective is difficult to establish as none of the staff with whom contact was established had referred to those in their care in these terms. However, the subsequent rise and support for UKIP in the region of this prison may offer some support for the notion that anti-immigrant and foreign national prisoner sentiment had some relevance in staff social discourse.

A further compounding factor was the erosion of opportunities in the prison for betterment. It has already been noted that the benchmarking process had stripped many of the assets including experienced staff from the prison. However, a further consequence of the transition to a foreign national prison was the removal of much of the rehabilitative and resettlement functions of the prison. As discussed above the risk 
levels of prisoners in the prison were often being raised due to Immigration interest and ROTL was being curtailed for many. However, other resettlement functions were also being eroded within the prison as the hubs and spokes policy took effect, that is, advice and guidance with regard to housing in the UK, the development of release plans and access to employment and other resettlement based agencies. The reasoning for this was made explicit in that if you were in the prison you were earmarked for removal whereas if you were to be released into the UK you should not be in the prison and would be moved elsewhere where those resettlement functions could be offered. This further entrenched the special status of the prisoners and for many was evidence that they were to be treated very differently from other prisoners and thus decreased the shared value base discussed above and the manner in which they perceived their incarceration.

Related to the above situation was the limiting of offending behaviour courses offered in the prison to a few places per annum on the Thinking Skills Programme. A number of prisoners had arrived in the prison having previously been told that they would need to complete specific offending behaviour programmes. As McNeil (2014) notes prisoners are expected to adhere to a punishment/rehabilitation paradigm, and for those in the prison this was the ethos which had underpinned their previous carceral experience. However, the hubs and spokes agreement (MoJ and UKBA, 2009) had resulted in the reduced function of the Offender Management Unit in the prison to a largely risk assessing body which meant that their facility to provide any form of offending behaviour work beyond that already mentioned was severely limited. The budget for such work had also been reduced as there was a perceived lack of need for the population in question. This exacerbated the situation and cemented the ideation that, as foreign national prisoners, they were placed beyond the normal realm of prisoner. This notion that their special status was the cause of the lack of opportunities afforded them in terms of rehabilitation and resettlement added to the general perception of legitimation crises as their carceral experience was now aparadigmatic. It is here that the deprivation of legitimacy becomes a discrete pain in and of itself and not just a consequence of penal conditions - the prisoners in this establishment were denied the usual predicates of a carceral sentence and thus denied both the very process and expectations by which, as a prisoner, they engaged in the legitimation process.

\section{Deprivation of Hope}

As foreign national prisoners deprived of certitude and legitimacy many viewed their situation as one absent of, or of diminishing, hope. As one Nigerian prisoner noted:

'Abandon hope all who enter here' you know this saying? That what this place like now. Not matter what you do, what rules are, how you behave, you get nothing, go nowhere. You tell people this, you tell ... No hope to find here.

Their inability to plan for a future, their insecurity where and when their release may come, their lack of access to the rehabilitative and resettlement processes and their placement beyond the normal boundaries of prison legitimation all conjoined to create a situation where the prisoners felt that any hope they may have clung to, throughout 
their sentence, was being taken from them (see also Bosworth, 2014). Some saw this as a distinct and distressing aspect of their experience as this prisoner, an Ivorian who had first settled in France before moving to England, explained: 'I had never thought of suicide before. I had gone through all my sentence, strong, planning for a future. Now I have no future. What is there for me? Nothing. Now I think of suicide.' Hope is a difficult concept to describe, and as such is limited in the literature on prisons, however, as Fromm (1968) argues hope is 'an intrinsic element of the structure of life, of the dynamic of man's spirit' and that its loss or prevention is experienced as a keen 'psychic and spiritual' assault which can result in a range of detriments to an individual's sense of self and, ultimately, to their well-being.

This was particularly evident in those whose family life was being severely impacted by their special status. As noted Immigration were earmarking all those housed in the prison as priority for removal regardless of what lives they had here. One father had asked: 'what of my children? What do I tell my children that they cannot see their father again?' This was a common refrain from the prisoners who had families and children (see also Ugelvik, 2014). There were degrees of distress evident in their recounting of their situations and 'hopelessness', 'despair', 'depression' and 'grief' were often terms related to their situation. Part of this pain was the lack of certitude that their families were subject to. Often they could not give their partners or children any firm answers on their situation, when their case may be resolved or how it may be resolved. This added stress upon stress as they knew they were creating further hurt for their loved ones but could not alleviate it. In this sense not only were they experiencing their own pains but vicariously that of their family too (Pope, 1987).

Even for those without children there were other sources of pain caused by a deprivation of hope. Maruna (2001) discusses the importance of the 'redemption script' in the process that desisters employ in the restructuring of their psycho-social narratives. The narrative tropes employed in these redemptive scripts are similar in nature to the 'Overcoming the Monster' (the self as offender), the 'Voyage and Return' (prison and release) and 'Rebirth' (the reformed self) tropes that underpin story and narrative construction (Booker, 2004). However, as noted the paradigmatic processes that prisoners have in order to shape or formulate these past, present and future narratives were curtailed in this prison due to the border control/deportation agenda (Kaufman, 2013). They were not able to participate in the preparatory rehabilitative and resettlement work that would enable them to overcome their offending past (the monster) and emerge (rebirth) as the desisting imago, the idealized notion of who they should be. In this sense many prisoners would become frustrated at their lack of progress and feel despair towards an unknown and unknowable self.

Lastly there were more pragmatic concerns that exacerbated this deprivation of hope. For many of those in the prison in order to have any chance of remaining in the UK they had to demonstrate their family ties and their wider ties to the communities from whence they had come. However, as with all prisoners the experience of imprisonment had inevitably weakened or even severed these ties making this extremely difficult (see Bosworth, 2012). One prisoner, an Indian man who had been living and operating a family business in the north of England for many years, noted 'before coming to prison I had job, I work hard, lived with my family ... all that gone now. How do I prove what my life was?' This inability to demonstrate or evidence their past and thus any legitimate reasons to remain in the country coupled with an inability to consolidate any future social capital, due to the precariousness of their 
situation, added to their sense of hopelessness. This was often reflected in the language that they used to describe their situation as foreign national prisoners which was one of 'defeat', or being 'beaten' by the system and of 'giving up':

They want you to give up and go. They want you to volunteer to go. To leave everything and go. This is what they want so they make you so sick, tired, that you give up ... that's their game. I used to fight but now? I just want out, I don't want to be in prison any more so I leave my family and go back to [omitted]. They have won and I have lost everything.

\section{Conclusion}

This article has argued that the foreign national prisoners held in one specialist prison suffered a range of new pains of incarceration that related to the deprivations of certitude, legitimacy and hope. The deprivation of certitude occurs when foreign national prisoners neither have any certainty over their release arrangements nor confidence in the processes by which their incarceration and cases are managed. In this setting legitimacy, which is a distinctly problematic notion in the case of IRCs and foreign national prisons, can be located in how foreign national prisoners perceive the justification for their incarceration as opposed to any material/procedural condition. As such the deprivations of legitimacy and legitimation crises arise when, often external, factors impact on the manner in which those justifications are perceived and the ideation of 'prisoner' is challenged. These two issues and their manifestation in this prison combine to erode the manner in which the foreign national prisoner is able to 'imagine' themselves beyond their current situation and thus results in a deprivation of hope.

These variegated pains can lead to both subjective and institutional problems that it is important for both academics and NOMS to be aware of and to take into consideration. There are distinct lessons for the prison service with regard to the development and entrenchment of expertise among their own personnel which would counteract the issue of staff becoming immigration 'postmen' as well as bridging the gaps between foreign national prisoners and front line staff. A further issue for the prison service is to ensure a degree of clarity in service between the standards outlined in the various PSI/PSOs and those requirements dictated by the hubs and spokes agreement. In terms of academia there is a wide range of questions that need exploration for little is still known about: foreign national prisoner experience; detainee experience in prisons; how staff perceive and work with foreign national prisoners and what challenges HM Prison Service faces with a growing foreign national population. Lastly, there is a need for greater dissemination of these issues - too much of what happens in prisons is hidden from the world. What happens with and to foreign national prisoners and detainees needs to be brought into the spotlight, examined, judged and, if needs be, challenged.

\section{Funding}

This research received no specific grant from any funding agency in the public, commercial or not-for-profit sectors. 


\section{Notes}

1. At the time of writing, there was also the possibility of further numbers of foreign nationals who had been sectioned under the Mental Health Act and would therefore be held in secure hospitals. I contacted the Immigration Service in order to establish this number but was informed that such data were not collected and thus the number remains unknown.

2. Though permission was sought and given by the Governor and those prisoners whom I have quoted to utilize, in academic publication, the accounts and examples given it was agreed that the prison would not be named directly and that respondent anonymity would be both assured and maintained.

3. A common law principle whereby individual X may be parasitically, or vicariously, guilty of a criminal act (V) performed principally by $\mathrm{Y}$ if $\mathrm{X}$ and $\mathrm{Y}$ were jointly involved in another criminal venture $(\mathrm{N})$. In this circumstance, $\mathrm{X}$ has, in some direct way, influenced the actions of principal actor $\mathrm{Y}$ in the commissioning of $\mathrm{N}$ and could reasonably foresee that $\mathrm{Y}$ would commit act V in the commissioning of act N (Smith and Hogan, 2011).

4. For an account of the experiences of foreign national prisoners within the broader context of the multicultural prison which goes beyond the scope of this article see Phillips (2012).

5. All quoted material is taken from field notes and permission to utilize was sought and agreed at the time. No identifiers are included in order to maintain anonymity.

6. Such pronouncements did little to endear this Home Office employee to prison staff, who, as Bosworth and Kaufman have both observed, find it difficult to reconcile the 'decency agenda' with border control (Bosworth, 2011; Bosworth and Slade, 2014; Kaufman, 2013).

\section{References}

Booker C (2004) The Seven Basic Plots: Why We Tell Stories. London: Continuum.

Bosworth M (2011) Deportation, detention and foreign national prisoners in England and Wales. Citizenship Studies 15(5): 583-595.

Bosworth M (2012) Subjectivity and identity in detention: Punishment and society in a global age. Theoretical Criminology 16(2): 123-140.

Bosworth M (2013) Can immigration detention centres be legitimate? Understanding confinement in a global world. In: Aas KF and Bosworth $\mathrm{M}$ (eds) The Borders of Punishment: Migration, Citizenship and Social Exclusion. Oxford: Oxford University Press.

Bosworth M (2014) Inside Immigration Detention: Foreigners in a Carceral Age. Oxford: Oxford University Press.

Bosworth M and Kaufman E (2011) Foreigners in a carceral age: Immigration and imprisonment in the United States. Stanford Law \& Policy Review 22(2): 429-454.

Bosworth M and Slade G (2014), In Search of Recognition: Gender and Staff-Detainee Relations in a British Immigration Removal Centre, Punishment \& Society, 16(2): 169-186.

Bottoms AE and Tankebe J (2012) Beyond procedural justice: A dialogic approach to legitimacy in criminal justice. Journal of Criminal Law and Criminology 102(1): 119-170.

Bhui HS (2004) The resettlement needs of foreign national offenders. Criminal Justice Matters 56(1): 36-44.

Bhui HS (2007) Alien experience: Foreign national prisoners after the deportation crisis. Journal of Community and Criminal Justice 54(4): 368-382.

Carlen P (1983) Women's Imprisonment: A Study in Social Control. Boston, MA: Routledge and Kegan Paul.

Carlen P (2013) Introduction: Women and punishment. In: Carlen P (ed.) Women and Punishment: The Struggle for Justice. Abingdon: Routledge.

Carrabine E (2005) Prison riots, social order and the problem of legitimacy. British Journal of Criminology 45: 896-913.

Cesaroni C and Peterson-Badali M (2010) Understanding the adjustment of incarcerated young offenders: A Canadian example. Youth Justice 10(2): 107-125. 
Cohen S and Taylor L (1972) Psychological Survival: The Experience of Long Term Imprisonment. Harmondsworth: Penguin.

Crewe B (2009) The Prisoner Society: Power, Adaptation and Social Life in an English Prison. Clarendon Studies in Criminology. Oxford: Oxford University Press.

Crewe B (2011) Depth, weight, tightness: Revisiting the pains of imprisonment. Punishment \& Society 13(5): 509-529.

Crewe B, Hulley S and Wright S (2014) Evidence to Justice Select Committee on the legal doctrine of joint enterprise. Available at: http://www.crim.cam.ac.uk/research/ltp_from_ young_adulthood/evidence_to_justice_committee.pdf (accessed 1 October 2014).

Earle R (2013) What do ethnographers do? Criminal Justice Matters 91(1): 18-19.

Engstrom DW (1997) Presidential Decision Making Adrift: The Carter Administration and the Mariel Boatlift. Lanham, MD: Rowman \& Littlefield.

Fagan J and Kupchik A (2011) Juvenile incarceration and the pains of imprisonment. Duke Forum for Law \& Social Change 3: 29-61.

Fromm E (1968) Revolution of Hope. New York: Harper \& Row.

Goffman E (1961) Asylums: Essays on the Social Situation of Mental Patients and Other Inmates. Garden City, NY: Anchor Books.

Habermas J (1975) Legitimation Crisis. Boston, MA: Beacon Press.

Hannah-Moffat K (2005) Criminogenic needs and the transformative risk subject: Hybridizations of risk/need in penality. Punishment and Society 7(1): 29-51.

Hernandez CCG (2013) Creating crimmigration. Brigham Young University Law Review 6: 1457-1515.

Hodkinson P (2005) Insider research in the study of youth cultures. Journal of Youth Studies 8(2): 131-149.

Home Office (1991), The Woolf Inquiry into Prison Disturbances, Home Office: February 1991, Kew: National Archives (HO 370).

Home Office (2014) Immigration Act 2014. London: The Stationery Office.

Hopkins PE (2007) Positionalities and knowledge: Negotiating ethics in practice. An International E-Journal for Critical Geographies 6(3): 386-394.

Jewkes Y (2005) Loss, liminality and the life sentence: Managing identity through a disrupted lifecourse. In: Liebling A and Maruna S (eds) The Effects of Imprisonment. Cullompton: Willan, 366-388.

Jewkes Y (2011) Autoethnography and emotion as intellectual resources: Doing prison research differently. Qualitative Inquiry 18(1): 63-75.

Jewkes Y (2014) An introduction to 'doing prison research differently'. Qualitative Inquiry 20(4): 387-391.

Kaufman E (2013) Hubs and spokes: The transformation of the British prison. In: Aas KF and Bosworth M (eds) The Borders of Punishment: Migration, Citizenship and Social Exclusion. Oxford: Oxford University Press.

Kaufman E (2015) Punish and Expel: Border Control, Nationalism and the New Purpose of the Prison. Clarendon Studies in Criminology. Oxford: Oxford University Press.

Kruttschnitt C, Dirkzwager A and Kennedy L (2013) Strangers in a strange land: Coping with imprisonment as a racial or ethnic foreign national inmate. British Journal of Sociology 64(3): 478-500.

Liebling A and Arnold H (2004) Prisons and Their Moral Performance: A Study of Values, Quality and Prison Life. Clarendon Studies in Criminology. Oxford: Oxford University Press.

Loader I and Sparks R (2013) Unfinished business: Legitimacy, crime control and democratic politics. In: Tankebe J and Leibling A (eds) Legitimacy and Criminal Justice: An International Exploration. Oxford: Oxford University Press. 
McDermott K and King R (1988) Mind games: Where the action is in prisons. British Journal of Criminology 28(3): 357-377.

McNeill F (2014) Punishment as rehabilitation. In: Bruinsma G and Weisburd D (eds) Encyclopedia of Criminology and Criminal Justice. New York: Springer, 4195-4206.

Maruna S (2001) Making Good: How Ex-Convicts Reform and Rebuild Their Lives. Washington, DC: The American Psychological Society.

Mason GL (1990) Indeterminate sentencing: Cruel and unusual punishment, or just plain cruel? New England Journal on Criminal and Civil Confinement 16(1): 89-120.

Ministry of Justice (MoJ) and UK Border Agency (UKBA) (2009) Service Level Agreement to Support the Effective and Speedy Removal of Foreign National Prisoners, http://www.irr.org.uk/pdf2/FNP_SLA.pdf 1 May 2015.

National Audit Office (NAO) (2005) Returning Failed Asylum Applicants. London: NAO.

National Audit office (NAO) (2014) Managing and Removing Foreign National Offenders. Home Office, Ministry of Justice and Foreign \& Commonwealth Office Report. London: NAO.

NOMS (2013) NOMS Business Plan 2013-2014. Available at: http://www.justice.gov.uk/downloads/publications/corporate-reports/noms/2013/nomsbusiness-plan-2013-2014.pdf (accessed 1 October 2014).

Phillips C (2012) The Multicultural Prison: Ethnicity, Masculinity and Social Relations among Prisoners. Oxford: Oxford University Press.

Pope V (1987) We all went to prison: The distress of prisoner's children. Probation Journal 34(3): 92-96.

Prison Reform Trust (PRT) (2015) Prison: The facts - Bromley briefings, summer 2015. Available at: http://www.prisonreformtrust.org.uk/Portals/0/Documents/Prison\%20the\%20facts\%20May\% 202015.pdf (accessed 20 July 2015).

Reich AD (2010) Hidden Truth: Young Men Navigating Lives in and out of a Juvenile Prison. Berkeley, CA: University of California Press.

Rotman E (1990) Beyond Punishment: A New View on the Rehabilitation of Criminal Offenders. Westport, CT: Greenwood Press.

Rowe A (2012) Women prisoners. In: Crewe B and Bennett J (eds) The Prisoner. Abingdon: Routledge.

Schuck PH (2013) Immigrant criminals in overcrowded prisons: Rethinking an anachronistic policy. Georgetown Immigration Law Journal 27(4): 597-748.

Simon J (1998) Refugees in a carceral age: The rebirth of immigration prisons in the United States. Public Culture 10(3): 577-607.

Smith JC and Hogan I (2011) Smith and Hogan's Criminal Law 13th Edition. Edited and updated by Ormerod D. Oxford: Oxford University Press.

Soni-Sinha U (2008) Dynamics of the field: Multiple standpoints, narrative and shifting positionality in multisited research. Qualitative Research 8(4): 515-537.

Sparks R, Bottoms AE and Hay W (1996) Prisons and the Problem of Order. Oxford: Oxford University Press.

Sykes GM (1958) The Society of Captives: A Study of a Maximum Security Prison. Princeton, NJ: Princeton University Press.

Teusner A (2015) Insider research, validity issues and the OHS professional: One person's journey. International Journal of Social Research Methodology. Epub ahead of print 20 March 2015. DOI: 10.1080/13645579.2015.1019263.

Thapar-Bjokert S and Henry M (2004) Reassessing the research relationship: Location, position and power in fieldwork accounts. International Journal of Social Research Methodology 7(5): 363-381.

Toch H (1992) Living in Prison: The Ecology of Survival. Washington, DC: The American Psychological Association. 
Tonry M (2004) Punishment and Politics: Evidence and Emulation in the Making of English Crime Control Policy. Cullompton: Willan.

Ugelvik T (2014) Paternal pains of imprisonment: Incarcerated fathers, ethnic minority masculinity and resistance narratives. Punishment \& Society 16(2): 152-168.

Van Der Lann A and Eichelsheim V (2013) Juvenile adaptation to imprisonment: Feelings of safety, autonomy and well-being and behaviour in prison. European Journal of Criminology 10(4): 424-443.

Walker S and Worrall A (2006) Life as a woman: The gendered pains of indeterminate imprisonment. In: Jewkes Y and Johnston H (eds) Prison Readings: A Critical Introduction to Prisons and Imprisonment. Cullompton: Willan.

Warr J (forthcoming) The prisoner: Inside and out. In: Jewkes Y, Bennett J and Crewe B (eds) Handbook on Prisons (revised 2nd edn). Abingdon: Routledge.

Wood N and King R (2014) Media and migration: An overview. In: King R and Wood N (eds) Media and Migration: Constructions of Mobility and Difference. Abingdon: Routledge.

Wrong DH (1995) Power: Its Forms, Bases and Uses. New Brunswick: Transaction Publishers.

\section{Author biography}

Jason Warr is a University of Lincoln Lecturer in Criminology with research interests in penology, sociology of power and the philosophy of science. Funded by an ESRC studentship his $\mathrm{PhD}$ is concerned with psychologists employed within British prisons and is entitled 'The prison based forensic psychologist: In person and practice'. 